\title{
Integrative potential of educational resources in a modern metropolis
}

\author{
Elena Markova ${ }^{1}$, Alina Pozdnyakova ${ }^{1 *}$, Tatyana Kolyadina $^{1}$, Darya Dmitriyeva ${ }^{1}$, and \\ Vladimir Zotov ${ }^{2}$ \\ ${ }^{1}$ Kosygin State University of Russia, Institute of International Education, Moscow, Russia \\ ${ }^{2}$ Kosygin State University of Russia, Institute of Social Engineering, Moscow, Russia
}

\begin{abstract}
The intensity of globalization and internationalization stimulates activity of population in the world. As a consequence, the number of Russian citizens living and getting education beyond the boundaries of the Russian Federation increases. Special load in this case is on the municipal structures rendering educational services in the Russian language. Quality improvement of teaching Russian and status of educational services in the Russian language are the social priorities and assume serious rearrangement of additional training of Russian language teachers. In this regard, it would be relevant to evaluate professional competences of Russian language teachers in schools abroad; to detect competence lacunas of additional professional education; to correct the detected professional deficits by additional educational programs of various specializations and degrees of complexity. This work is aimed at detection of development strategies of the Center as a tool of distance support for Russian schools abroad. The research methods in this work are theoretical analysis of psychologic and pedagogical, sociological, economic publications devoted to the considered problem; analysis of practices of distance support courses in Russia and abroad; surveying, testing users of existing courses; analysis of expert opinions and quality appraisals of online training; analysis of statistic data. The activity of such Center would promote implementation of the Russian Schools Abroad concept, providing opportunity of annual systematic diagnostics of state of educational and methodological resources of foreign schools, supplying Russianists with modern methodological tools, allowing foreign schools to systematically raise the level of professional competences of teaching staff.
\end{abstract}

Keywords: educational courses, professional competences, Russian Schools Abroad, distance learning.

\section{Introduction}

The state policy in the sphere of education based on legislative acts and considering for features of the regions, where the educational structures are located, is aimed at implementation of constitutional right of citizens for education of all levels (preschool,

* Corresponding author: apozdnyakova@live.ru 
elementary, basic, secondary, professional, higher), including that provided in the Russian language abroad.

Close attention to foreign schools in our times is not accidental and is associated with the intensity of globalization and internationalization, causing sharp increase in population mobility in many countries and regions [1], which results in increase in the number of Russian citizens living and getting education beyond the boundaries of the Russian Federation. Special load in this case is on the municipal structures rendering educational services in the Russian language, the role of metropolises as urbanistic conglomerates possessing high potential in the sphere of integration of scientific and educational resources is increasing.

Quality improvement of teaching the Russian language and status of educational services in the Russian language are the social priorities and assume serious rearrangement of professional development of Russian language teachers (Russian as a foreign language: RFL, Russian as a nonnative language: RNL), as well as reconsideration of approaches to additional professional education of teachers in whole [2-4]. At present, it is obvious that only permanent updating and intensification of teacher's professional training, namely, of RFL teacher, are capable to provide high level of language competences of students and stimulate promotion of the Russian language in socio-cultural space. In this regard, the relevant issues are: 1) evaluation of professional competences of Russian language teachers of foreign schools; 2) detection of competence lacunas of additional professional training; 3 ) correction of the detected professional deficiencies by additional educational programs of various specializations and degrees of complexity.

Especially important for evaluation of professional competences of Russian language teachers in foreign schools and detection of competence lacunas of additional professional education is diagnostic testing, i.e., a system of tests assuming integrated evaluation (metering) of teacher's activity from three positions: 1) in terms of subject knowledge, 2) in terms of organization and methodology, 3) in terms of psychology. In this case, testing acts as a tool and as a method of pedagogical metering.

Testing as a metering tool assumes development of standard assignments with certain qualitative and quantitative properties, allowing to detect the level of formation of professional competences of tested persons: teachers of foreign schools. Testing as a method is the technology of metering including standard procedure of evaluation and methods of statistic processing, analysis, and interpretation of the obtained results [5-7].

Correctly arranged system of testing diagnostics allows not only to give objective evaluation of professional training state of Russian language teachers in this or that country, but also reveals professional deficits, which can and should be corrected by additional educational programs of various specializations and degrees of complexity.

It seems to be reasonable to combine diagnostic and educating components of additional professional education in the frames of single continuously acting resource - Center of professional adaptation of Russian language teachers in foreign schools acting on the basis of state educational structure of metropolitan region and performing coordinating, regulating, educational, informative, accounting and other functions.

The activity of such Center would promote implementation of the Russian Schools Abroad concept, providing opportunity of annual systematic diagnostics of state of educational and methodological resources of foreign schools (and universities), supplying Russianists with modern methodological tools, allowing foreign schools to systematically raise the level of professional competences of teaching staff. This explains the relevance and social importance of this work.

This work is aimed at definition of development strategies of the Center of professional adaptation of Russian language teachers in foreign schools, which is being established on the basis of Russian State University named after A.N. Kosygin, and its use as a tool of distance support and provision of educational process in the Russian language. 
The following tasks are being solved:

- development of concept of the Center as an element of educational space of metropolis,

- development of concept of digital diagnostic tests allowing to detect the level of formation of professional competences of teachers in foreign schools,

- definition of analysis of diagnostic testing results aiming at detection of deficits in professional competences and evaluation of state of teaching the Russian language in certain regions,

- determination of mechanisms of implementation and distribution of new models, methods, forms and technologies of education (mainly electronic and distance education: video lectures, webinars, online conferences, etc.) in the frames of programs of additional professional education.

\section{Methods}

The research methods in this work were theoretical analysis of psychologic and pedagogical, sociological, economic publications devoted to the considered problem; analysis of practices of distance support courses in Russia and abroad; surveying, testing users of existing courses; analysis of expert opinions and quality appraisals of online training; analysis of statistic data $[8,9]$.

The concept of diagnostic actions was based on provisions of the demand and information theory by V.P. Simonov [10] and personalized activity approach to training by P. Ya. Galperin and N.F. Talyzina $[11,12]$, adapted for analysis of interaction of subjects in digital information environment. In addition, the proprietary procedure of expert appraisal of Russian educational environment abroad was used, allowing to analyze the orientation of educational content of Russian school with regard to formed competences of students. The developed digital expert toolkit was verified in practice: upon diagnostics in Russian schools in the cities of Czechia and Slovakia.

The concept of educational modules was based on the approaches used in the theory and practice of language teaching: communicative, socio-cultural, problematic, competence. The analysis was applied to open courses providing continuous professional training of RFL teachers [13], including massive open online courses, online lectures, scientific webinars, online lessons, scientific conferences $[14,15]$.

The technological basis of the digital educational resource, the Center of professional adaptation of Russian language teachers in foreign schools, was duplex training system using intelligent simulators developed by O.I. Lisov and implemented upon arrangement of website: "Class of Professor Oleg Ivanovich Lisov". He believed that such system was optimum for formation of educational resources, since it provided variance of education and cognition of knowledge actualization with accounting for psychological and other individual properties of trainees on the basis of abductive method of training [16].

\section{Results}

The main result of the research is the development of operation mechanism of the Center of professional adaptation of Russian language teachers in foreign schools, performing systematic diagnostic and education events.

The developed course as a tool of distance support of educational process is characterized by all basic properties of such resource. These are: 1) feedback; 2) opportunity to store information about the training process (intermediate stages) at the educational complex; 3 ) opportunity to correct training by teacher on the basis of obtained data during training; 4) system flexibility (response to student's actions) [16]. 
Arrangement of the portal (website) of distance education is universal: it has tree architecture providing opportunity of free transitions both from the main site page and from any other page to the required section, subsection, required page of the resource.

The main page of the portal (website) as the most meaningful is referred to the first level of system hierarchy and includes standard set of categories and options: 1) About, 2) Registration, 3) Navigator. The second level is comprised of the subcategories providing user navigation towards selection of target group (Russian school, Russian language courses, Sunday school) and type of requested information (question, training course, online tutor, library, to pass test). At the third level, new subcategories are shown (for instance, for question: quick question, consultation, checking; for training course: specification of training courses; for test: specification of diagnostic tests). At the fourth and the fifth level, the most frequent subcategories are highlighted. Since this resource provides reference information, a system of quick transitions to news pages, vocabularies and reference books is developed.

In order to optimize searching, it is possible to create the site map in the format clear for search robot. Availability of such map allows rapid review and indexing of all resource pages.

Correct site structure is background of its success and efficiency; however, the most significant is, of course, meaningful content of the resource assuming highlighting of two main modules: diagnostic and educational. Formation of complete diagnostic module allows: 1) to detect and to evaluate the level of subject, psychological and pedagogical competences of teachers in Russian schools abroad, and 2) to develop the strategy of correction of their professional competences. Filling the training module allows: 1) to improve the level of professional competences of teachers; 2) due to online format, to provide access to actual methodological knowledge for most teachers-Russianists; 3) to familiarize them with opportunities to use Russian online resources in the sphere of teaching foreign languages.

We suppose that the developed program of advanced training as well as methodological materials, services for RFL teachers and foreign citizens can be widely applied in the system of Russian additional training.

\section{Discussion}

Increased requirements to the quality of rendered educational services lead to reconsideration of traditional approaches to additional professional training. It is obvious that unsystematic character, excessive utilitarian attitude, and insufficient methodological freshness of programs, which are sometimes proposed to trainees, cannot sufficiently improve the professional level of Russianists teaching foreign citizens and our compatriots abroad. Even in the case of high amounts (72-118 academic hours), the programs of advanced training turn to be useless, since do not consider for numerous important properties determining efficiency of educational process.

We believe that the main such characteristic is the specificity of targeted audience, at which the educational program should be oriented. The targeted audience is stipulated by the type of educational establishment, where the Russian language is taught or education is performed in Russian. It is obvious that the methodological demands of a teacher working in a school at the Russian Embassy or in educational establishment organized in accordance with international treaties of the Russian Federation differ from those of a Russianist teaching in a foreign establishment (governmental or nongovernmental), performing educational activity according to main and/or additional general educational programs totally or partially in the Russian language. These demands are not differentiated and not taken into account anywhere, though there are numerous variants of educational establishments (Russian schools). Without consideration for specificity of Russian school, it is difficult to develop a route of professional improvement of pedagogical staff. Additional professional training is 
reasonable only after extensive diagnostics aimed at detection of lacunas at various levels of professional activity (subject, organizational and methodological, psychological, etc.).

Analysis of works devoted to testing of professional competences of pedagogical staff involved in open education in the Russian language and teaching the Russian language allows to conclude that there are significant contradictions in comprehension of the essence of subject diagnostics, when the latter is interpreted as "diagnostics of level of training" [17, 18]. Such narrow approach actually excludes control of formation of key skills and, respectively, does not allow to detect competence lacunas in teacher's activity.

We believe that the concept of diagnostic testing should be aimed at determination of the vector of professional development of a teacher and be based on two postulates: systematic pattern of performed diagnostic actions and respect of professional independence of a teacher.

The concept structure assumes the existence of: 1) basis determining regularities, principles, functions of diagnostic testing, and 2) superstructural elements: meaningful content and technological tools allowing to implement the concept in the system of additional professional education.

In order to eliminate the competence insufficiency, it is necessary to implement programs of additional professional education, developed with consideration of practical orientation of the proposed content, on the one hand, and preferences of targeted audience, on the other hand. It would be reasonable to implement such programs in distance mode in the frames of courses of advanced training at least once a year. We consider opportunities to implement these programs on the platform of established Center of professional adaptation of Russian language teachers in foreign schools, operating as an educational resource in Moscow.

\section{Conclusion}

The project of foundation of the Center provides potentials for the use of educational resource in further activity: for support of Russian schools abroad, popularization of Russian educational programs, formation of positive image of Russian science and Russian education. In addition, it becomes really possible to include this resource into the system of interaction with educational establishments (universities, colleges, cultural centers) in various countries, which will promote development of environment for studying the Russian language abroad; promotion of Russian educational services in global market.

\section{References}

1. Concept "Russkaya shkola za rubezhom [Russian Schools Abroad]" (approved by the President of the Russian Federation on 04.11.2015 No. Pr-2305). Accessed on: September 09, 2020. [Online]. Available: http://www.kremlin.ru/acts/news/50643

2. E.G. Azimov, Informatsionno-kommunikatsionnyye tekhnologii v prepodavanii russkogo yazyka kak inostrannogo [Information and communication technologies in teaching Russian as a foreign language] (Russkiy yazyk. Kursy, Moscow, 2012)

3. A.K. Zharkenov, Pedagogicheskaya nauka i praktika, 3(21), 27-31 (2018)

4. Ye.N. Klochkova, N.A. Sadovnikova, Open education, 23(4), 13-22 (2019). https://doi.org/10.21686/1818-4243-2019-4-13-22

5. V.S. Avanesov, Osnovy nauchnoy organizatsii pedagogicheskogo kontrolya v vysshey shkole [Fundamentals of the scientific organization of pedagogical control in higher education] (MISIS, Moscow, 1989)

6. V.S. Avanesov, Upravleniye shkoloy, 12, 98 (1999) 
7. V.Yu. Pereverzev, Kriterial'no-oriyentirovannyye pedagogicheskiye testy dlya itogovoy attestatsii studentov [Criteria-based pedagogical tests for the final certification of students] (Scientific Methodological Center of Secondary Professional Education of the Ministry of Education of the Russian Federation, Moscow, 1999)

8. V.P. Bespalko, Programmirovannoye obucheniye. Didakticheskiye osnovy [Programmed learning. Didactic foundations] (Vysshaya shkola, Moscow, 1970)

9. V.S. Kim, Testirovaniye uchebnykh dostizheniy [Testing of educational achievements] (Ussuriisk, USPI Publishing House, 2007)

10. P.V. Simonov, Voprosy psikhologii, 6, 44-56 (1989)

11. P.Ya. Galperin, Vvedeniye v psikhologiyu [Introduction to psychology] (Universitet, Moscow, 1999)

12. N.F. Talyzina, Upravleniye protsessom usvoyeniya znaniy [Management of the process of assimilation of knowledge] (Moscow State University, Moscow, 1975)

13. V.N. Klimova, IK. Nefedova, Sozdaniye sistemy distantsionnoy professional'noy podderzhki kak instrument obespecheniya nepreryvnogo obrazovaniya prepodavateley RKI [Creation of a system of distance professional support as a tool for providing continuous education for teachers of RFL], in Proceedings of the International scientific and practical conference "Elektronnyye resursy otkrytogo obrazovaniya po russkomu yazyku: luchshiye praktiki [Electronic resources of open education in the Russian language: best practices]", Pushkin State Russian Language Institute, 7-8 December, 2017, Moscow, Russia, 66-71 (2018)

14. V.S. Tretyakov, V.A. Larionova, Higher education in Russia, 7(203), 55-66 (2016)

15. E.G. Azimov, Russian language abroad, 4(263), 12-18 (2017)

16. O.I. Lisov, Ekonomicheskiye i sotsialno-gumanitarnyye issledovaniya, 3(4), 109-116 (2014)

17. D. Keegan, Foundations of Distance Education (Routledge Taylor and Francis Group, New York, 1996)

18. D. Newman, Top 6 digital transformation trends in education, Forbes, (2017). Accessed on: September 09, 2020. [Online]. Available: https://www.forbes.com/sites/danielnewman/2017/07/18/top-6-digital-transformationtrends-in-education/?sh=161e $7 \mathrm{bcd} 2 \mathrm{a} 9 \mathrm{a}$ 